\title{
Improving Halal Traceability Process in the Poultry Industry Utilizing Blockchain Technology: Use Case in Indonesia
}

\author{
Larissa P. Sidarto ${ }^{1 *}$ and Aditya Hamka ${ }^{2}$ \\ ${ }^{1}$ Saïd Business School, University of Oxford, Oxford, United Kingdom, ${ }^{2}$ Faculty of Economics and Communication, Bina \\ Nusantara University, DKI Jakarta, Indonesia
}

Demand for Halal food has significantly increased with the growing Muslim population and society's interest in sustainable food production. However, there has been an increase in concerns regarding the Halal food labeling transparency process, with misleading labels found across the world. Blockchain-based traceability systems are a potential solution for current limitations in monitoring the production process of food due to its inherent decentralization and immutable nature. The technology allows stakeholders, including consumers, to promote farm-to-fork transparency, where traceability is a core component. This paper will explore the blockchain-based traceability system use case implemented by the Indonesian poultry player PT Sreeya Sewu Indonesia Tbk. Utilizing a blockchain-based system as a foundation for traceability shows promising results: data throughout the process is recorded permanently and difficult to tamper. Although the system does not eliminate the possibility of incorrect information being recorded, the same immutability characteristics will keep the new knowledge of fraud permanent if found during the audit.

OPEN ACCESS

Edited by: Alicia Noel,

Cultivati Inc., United States

Reviewed by: John G. Keogh,

University of Reading, United Kingdom Marc Rocas-Royo,

Open University of Catalonia, Spain

*Correspondence:

Larissa P. Sidarto

larissa.sidarto@gmail.com

Received: 01 October 2020

Accepted: 16 June 2021

Published: 15 December 2021

Citation:

Sidarto LP and Hamka A (2021) Improving Halal Traceability Process in the Poultry Industry Utilizing Blockchain

Technology: Use Case in Indonesia.

Front. Blockchain 4:612898.

doi: 10.3389/fbloc.2021.612898
This layer of accountability contributes to the transparency that benefits both the consumers and stakeholders of the value chain.

Keywords: blockchain, decentralization, halal traceability, poultry, transparency, supply chains

\section{INTRODUCTION}

Halal-certified global demand for food is growing with the rising Muslim population and society's interest in sustainable food production. According to Withnall (2014), Muslim food consumption must meet Islamic dietary guidelines, generally known as Halal. Pew Research (2018) predicts that the Muslim population will expand to be the largest religious group worldwide in the next 50 years. Unsurprisingly, the Halal food industry market is expected to more than double and become a $\$ 3.2$ trillion market by 2024 (Dinar Standard, 2018). Besides catering to the growing Muslim population, the Halal food industry is an emerging market force that attracts non-Muslims due to its perceived sustainable production. Ali and Suleiman (2016) found that the Standard Halal Food and Lowell Center for Sustainable Production guidelines are well aligned. Thus, a Halal label could assure consumers regarding the quality of their foods (Mayasari, 2018). With a demand increase from Muslims and non-Muslims alike, the market for Halal-certified food has promising prospects.

However, there have been debates regarding the integrity of the Halal labeling process itself. Consumers are starting to question whether food with Halal labels indeed follows the required Halal food production process requirements. Zailani et al. (2010) found that several Halal food producers 
in Malaysia did not conform to the Halal requirements set by the Malaysian Islamic Authority. Multiple scandals, such as the discovery of misleading Halal labeling on machine-slaughtered chicken and catfish fed with Haram materials, were found (Rashid et al., 2018). According to Spink et al. (2019), the rampant mislabeling can be categorized as food fraud, threatening the integrity of Halal labeling even further. This discovery raised doubts on whether the current Halal traceability in the market is credible and effective.

The process of recording information throughout the production process is opaque, thus prone to data tampering that is difficult to trace. A system that traces the origin of the food and its treatment should address concerns of consumer regarding the integrity of Halal labeling process (Rejeb, 2018). There are attempts to create traceability systems, yet with several limitations: information on the process is still recorded offline and then manually entered into the system (Zailani et al., 2010). The traceability system implemented should ensure that information is verifiable, increasing security from manipulation.

The inherent nature of decentralizing information of blockchain technology is a traceability solution. This feature is essential as the agri-food supply industry structure is complex. Dubbed as the "trustless trust" (Deloitte, 2020), records on blockchain are distributed to all parties involved instead of being centralized to a single authority. As a result, any attempts to tamper information become difficult. A multiingredient food product, for example, will require several business entities to exchange information multiple times instead of a single ingredient product (Rejeb et al., 2020). Blockchain allows opportunities to effectively collaborate, as its immutable feature builds trust between parties.

This paper will review the implementation of digitizing traceable poultry production utilizing blockchain technology, enabling consumers to trace information, and decide whether the product is indeed Halal. Two research questions in this paper will be: 1) What is missing in the current Halal labeling assessment? 2) How can blockchain improve the Halal labeling assessment? By assessing a use case on a blockchain-based traceability system implemented at PT Sreeya Sewu Indonesia Tbk, this paper aims to illustrate how blockchain technology can improve halal traceability for poultry.

\section{Halal Definition}

According to Withnall (2014), food consumed by Muslims must meet Islamic dietary guidelines, generally known as Halal. The term comes from the Arabic word halāl (حلال), which means "things or activities permitted by Islamic Law." Halal is not just about the slaughter of animals, alcohol use, or the sources of food and beverages but also about standards and processes. It outlines safety, cleanliness, reliability, and quality assurance.

The opposite of Halal is Haram (حرام), which means something or activities that Islamic Law prohibits. Halal and Haram are common Islamic terms used in product lines such as food and drinks, cosmetics, medicine, and makeup. Should a product not fall in either the Halal or Haram category, then it is Mashbooh, meaning unclear whether it is Halal or not.

Guidelines to select Halal food have been stated explicitly in several Quran verses that urge Muslims to choose only permitted food: "Eat of the things which Allah has provided for you, lawful and good; and fear Allah, in whom you believe" (Al-Maida 5:88).

Majelis Ulama Indonesia (Indonesian Ulama Council), or MUI, is Indonesia's highest Muslim clerical body. It is instrumental in issuing and formulating regulations relating to the Quran, such as Halal fatwas (a formal interpretation of Islamic law given by a qualified legal scholar). MUI (2019) and MUI (2020) stated that Halal food could become Haram, if it is treated by using non-Halal procedures, such as the following;

- The slaughtering process is not conducted by a Muslim or without the mention of Allah's name.

- It uses an unsharpened knife.

- During the slaughtering process, the blood of the animal is not drained out completely (Muslims are forbidden to eat the blood of animals).

- If it is contaminated or mixed with Haram substances. The contamination with non-Halal substances might occur during some processes, such as mixing the Halal animal flesh with non-Halal materials (raw materials, herbs, or equipment). Meat, for example, is considered Haram if the processing location or equipment is also used for non-Halal handlings.

\section{ISSUES AND PROBLEMS REGARDING INTEGRITY OF HALAL FOOD LABELLING}

\section{Issues in the Integrity of the Halal Food Labeling Process}

According to Khasanab and Wardah (2018), having a Halal label attached to food provides consumers with assurance regarding the halal process integrity. Halal food integrity ensures that all food consumed by Muslims is truly Halal and follows the Quran rules, such as free of contamination by any non-Halal substances throughout its supply chain processes. The Halal concept refers to the whole process of food production, which includes controlling, packaging, storing, and delivery processes (Alam and Sayuti, 2011).

However, according to Ibrahim (2012), current Muslim consumers are unsure whether all Halal-labeled food is actually Halal. Rashid et al., (2018) found that the rising number of misuse of Halal labels indicates that there are weaknesses in the procedure of determining Halal food. In 2010, Malaysian authorities found that some Halal food producers do not follow the rules and requirements set by JAKIM, the Muslim organization in Malaysia responsible for Halal certification (Zailani et al., 2010). In 2012, Indonesian authorities found cases where Halal-certified processed beef products have been mixed with pork and distributed across the nation (Tempo, 2012). Anonymous (2014) found that Cadbury chocolate products (Chocolate Dairy Milk and Chocolate Dairy Milk Almond) contained porcine. This finding on the Cadbury case resulted from a random sampling test conducted by the Malaysian Ministry of Product from store 
samples in Perlis and Kedah. Rahim and Ma'aram, (2016) shared a finding of Malaysian food producers that applied false Halal logos to mislead consumers while knowing that their products contain non-Halal ingredients.

Another concern raised regarding the integrity of Halal labeling process is that Halal manufacturers come from various parts of the world (ASEAN Post Team, 2019), resulting in different interpretations and labeling standards. Research conducted by the Dubai Islamic Economic Development Centre and Thomas Reuters (2016) found that the biggest exporters of Halal food are non-Muslim majority countries like Brazil ( $\$ 5.2$ billion), followed by Australia ( $\$ 2.4$ billion), India ( $\$ 2.3$ billion), France, China, and Sudan. Concerns arise whether the Halal material is treated separately from non-Halal substances. The food can be considered Haram due to the indirect contamination with the non-Halal materials.

Thus, according to Rashid et al. (2018), it is important to implement Halal supply chain strategies to guarantee the quality of Halal food and boost the trust of consumers.

\section{Halal Certification Process in Indonesia}

The Pew Research Center (2019) states that Indonesia has the largest Muslim population globally, with approximately 220 million Muslims in 2015. Halal certification for products (including but not limited to foods, cosmetics, pharmaceuticals, and clothing) was exclusively managed by the Muslim clerical body of the country, MUI (Detik, 2019). In 2019, the Indonesian government gave mandates to two governing bodies: MUI with authority to issue a fatwa - an interpretation or opinion based on Islamic Law issued by qualified Islamic jurists to determine the Halal status of a product, and the Badan Penyelenggara Jaminan Produk Halal (BPJPH) of the Indonesian Ministry of Religion, with the authority to issue Halal certifications.

According to Riana (2019), obtaining Halal food certification in Indonesia goes as follows:

- The Halal food business (requestor) needs to register and submit the required documents.

- The BPJPH will then examine the requirements submitted.

- Postdocumentation submission, the requestor selects the Halal inspection institution to inspect their products.

- The results of the Halal inspection institution will then be sent to the MUI as the fatwa creator.

- If MUI approves the results, then BPJPH will issue the Halal certificate to the requestors.

- Starting from October 2019, Halal certificates are valid for 4 years. However, there is a grace period of 5 years for socialization purposes. Therefore, the current existing Halal certification issued by the MUI is still valid (Kurnia, 2019).

The MUI has created an application called Halal MUI. One of the features of this application is to verify the validity and authenticity of a Halal logo on the food label by using barcode scanning. However, this application cannot track the origin of the food, which could boost the trust of consumers by providing more transparency (Lithalia, 2016).

\section{Limitations in Infrastructure and Resources}

The credibility of Halal labels in Indonesia largely depends on robust infrastructure and existing resources to implement an effective halal labeling process. Earlier, the MUI has mentioned that human resources and budget limitations hinder the continuous monitoring of the end-to-end Halal process (Tempo, 2012). There is currently no infrastructure/system to check and track the Halal status of products, especially foods. A study conducted by Anir et al. (2008) finds that consumers have concerns regarding the authenticity of a Halal logo and certificate due to the possible duplication of logos and documents by an unauthorized party.

Norman et al. (2008) found the following problems in Halal tracking: 1) The absence of systems to track processes on a realtime basis, increasing doubts that production follows the laws from the Quran and 2) Minimal and centralized infrastructure oversight allows manipulation of Halal labeling. Most existing systems operate on a manual basis, while the few web-based systems can only track the Halal food list. Opaque and centralized systems do not address the trust issues of the labeling process.

\section{TRACEABILITY AND BLOCKCHAIN}

\section{How Traceability Assists Halal Verification Process}

Traceability increases the integrity of the Halal labeling process as it promotes information transparency throughout the supply chain. Traceability is "the ability to discern, identify and follow the movement of a food or substance intended to be or expected to be incorporated into a food, through all stages of production, processing, and distribution" (FAO, 2017). Information sharing on products and processes involving effective collaboration between stakeholders in the value chain are important to ensure the integrity of halal products (Saifudin et al., 2017; Rohmah and Maharatin, 2019). Therefore, traceability systems are tools to help food producers manage information flow and the quality of products.

\section{Blockchain to Promote Halal Traceability}

A blockchain-based traceability system in the Halal-labeling process allows transparency of the journey of the product. Instead of the end-product seller being solely responsible for relaying information, each party involved in the value chain must bear responsibility. Blockchain technology utilizes a chain of blocks that contains data and information. Each block consists of three parts: data, unique ID (hash), and previous hash. These blocks are linked in a peer-to-peer network and the unique ID (hash) changes if the information is edited, making it difficult to tamper with the information (Viriyasitavat and Hoonsopon, 2019).

There are two main characteristics of blockchain technology:

- Secure and immutable

Once data is stored in the blockchain (new block created) and other participants have agreed on this state, it is difficult to 


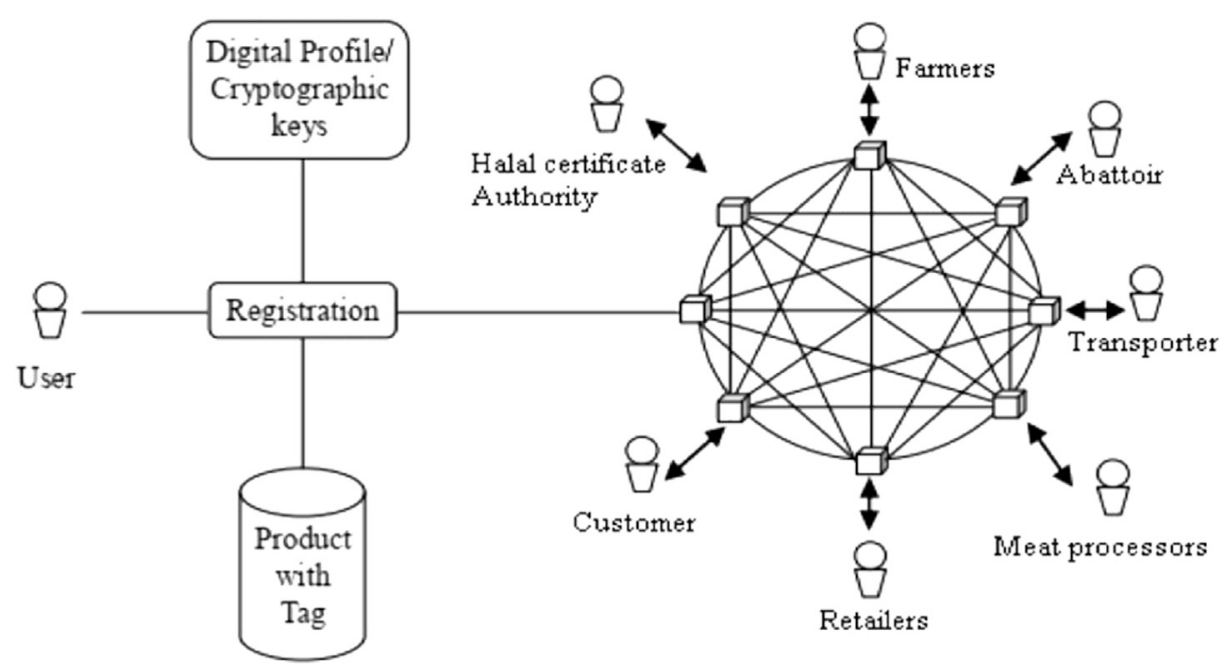

FIGURE 1 | Conceptual Framework of the Halal Meat System. Source: Rejeb, A. (2018). Halal Meat Supply Chain Traceability Based on HACCP, Blockchain and Internet of Things. Acta Tech. Jaur 11 (4), 218-247.doi:10.14513/actatechjaur.v11.n4.467.

change. As a block is created, and a unique hash ID will automatically be added. Each block consists of its unique hash and the previous block hash. If someone attempts to tamper data within the block, the hash will be replaced by a new one. This will cause an error in the next block, as the next block still records the previous hash.

\section{- Decentralized ledger}

Blockchain technology uses a peer-to-peer network to manage the chains, which means each party in the chain will get a copy of the blockchain. Any changes or addition to the data will be notified to all users (Reiff, 2020). As all network stakeholders have a copy of the blocks, they can see and trace all the historical data based on the blockchain.

The main characteristics of blockchain technology of secure, immutable, and decentralized ledger can enhance the traceability of the Halal labeling process. The technology allows transparency of information as stakeholders, such as consumers, can trace data recorded from farm to fork. This capability boosts the consumers' trust regarding the Halal labeling process of the food purchased (Figure 1).

There are two main advantages of implementing a blockchain system for Halal traceability:

- Enhance the credibility and accountability of the Halal labeling process

Data stored in different servers prevent data manipulation. If someone tries to manipulate the data, the other parties in the chain will be notified. For example, a chicken slaughterer cannot change the status of an animal recorded by the veterinarian as ill to healthy without notifying everyone within the network. This helps to boost Halal consumer trust in the Halal integrity of the products.
- Trace the production process

Stakeholders, including consumers, can trace the origin and process of the food supply chain. The transparency of the system provides all parties within its food supply chain with access to the same information, including attestations (acknowledgment of the authenticity of the information) which reduces communication or transfer data errors (Deloitte, 2020).

\section{The Risk of Incorrect Data}

The decentralized characteristics of the blockchain technology reduce data tampering but do not eliminate the possibility of incorrect information being recorded on the system. If the data recorded is incorrect or intentionally misrepresented and agreed by the required participants, it will be recorded permanently. The system is dependent on an imperfect world, in which human error or mischief is possible. The same immutability characteristics, on the other hand, help in such a situation. If data is found to be incorrect in an audit, it will be appended with the information that it was incorrect-and this information will never be forgotten. The immutability characteristics will keep the new knowledge of fraud information permanent.

\section{SREEYA SEWU USE CASE: HALAL TRACEABILITY IMPLEMENTATION FOR POULTRY IN INDONESIA}

\section{Sreeya Sewu Use Case Overview}

PT Sreeya Sewu Indonesia Tbk (Sreeya Sewu), a major poultry player in Indonesia, implemented a blockchain-based traceability system for its chicken slaughtering process. Although its products have already been certified Halal by the MUI, the company realized there is an increasing global trend of consumer concern regarding 


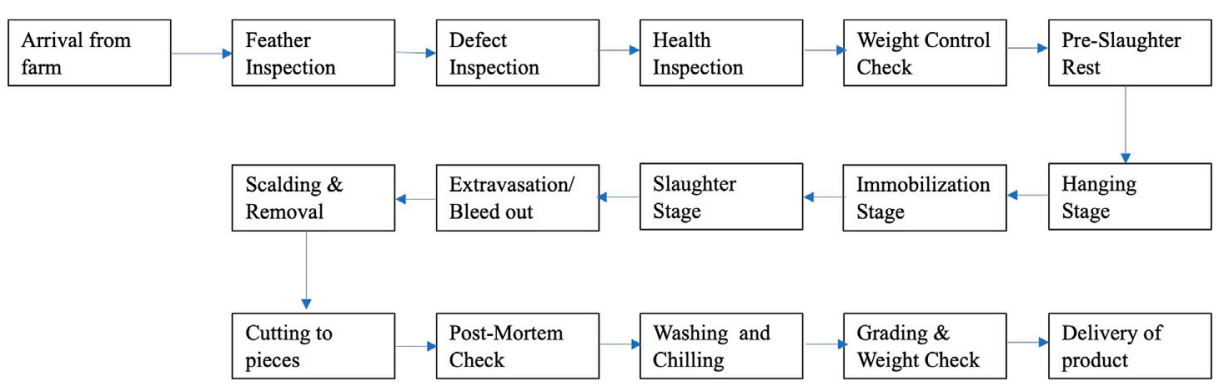

FIGURE 2 | Overview Poultry Slaughtering Process. Source: HARA (2020). Internal Company Data. HARA.

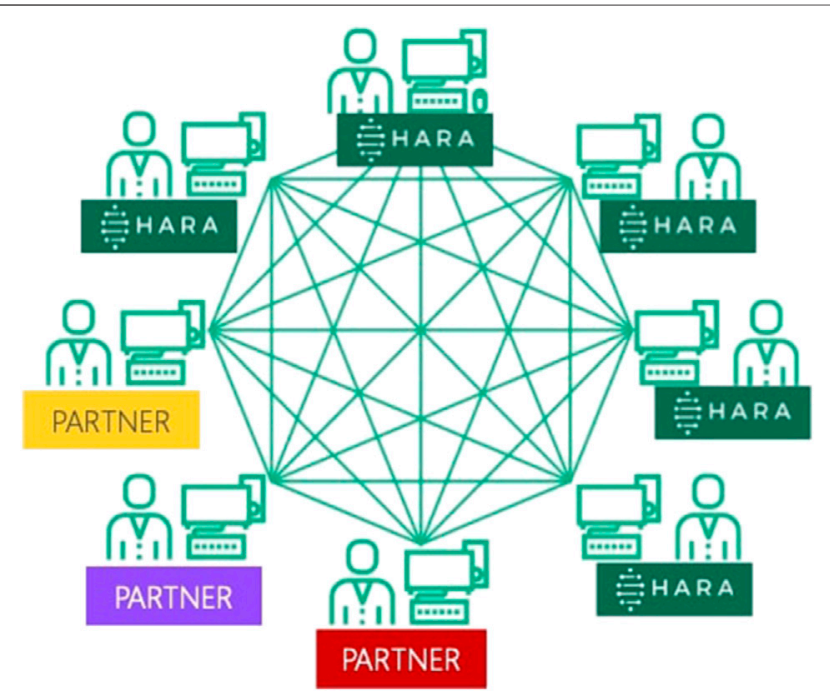

FIGURE 3 | HARA Ledger. Source: HARA (2020). Internal Company Data. HARA.

Halal certification assurance labels on food products. Sreeya Sewu collaborated with blockchain-based company HARA and data analytics firm Dattabot to implement a traceability system utilizing blockchain-based technology (Tempo, 2012). The implementation of Sreeya Sewu's blockchain-based traceability system for Halal poultry is the first known use-case in Indonesia, allowing transparency of the slaughtering process while simultaneously digitalizing the flow of information.

\section{Identifying Critical Paths Towards a More Credible Halal Poultry}

Implementing a blockchain-based traceability system aims to bring transparency of information by allowing customers to trace the journey of the poultry at the slaughterhouse. Thus, checkpoints deemed critical for the Halal assessment of the journey of the poultry from arrival to the quality grading process of the carcass are recorded on the system.

The recording process starts from the arrival of the poultry at the slaughterhouse (Figure 2). Granular ante-mortem inspections are then executed, such as:
- Feather inspection: the initial process involves checking whether the feathers of the poultry are dry to ensure accurate weight measurement. Poultries with wet feathers are separated to dry first.

- Defect inspection: poultries with defects past a certain threshold will be rejected from the process and returned to the provider.

- Health inspection: according to the Quran, Muslims should not eat food from animals deemed sick. Thus, the poultries that do not pass the health inspection will be destroyed immediately.

- Weight-control check and pre-slaughter rest: after going through a weight-control check, the poultries are given a pre-slaughter rest. The rest stage is critical, as animals should not be distressed before slaughter (Rahman, 2017).

The poultry that passes inspections will receive various treatments (e.g., hanging, stunning, slaughtering, extravasation, feather removal, neck cutting, and cutting). Waste from the process, such as blood and feathers, considered Haram, are separated from the poultry meat and discarded. The carcass will go through the hanging process again. Its cloaca (i.e., single posterior opening for the digestive, urinary, and reproductive tracts of a bird) will then be cracked to remove the innards, heart, and liver. The cleanliness of the carcass will then be inspected. If the carcass is clean, it will be soaked in cold water before being stored in the chilling room. The production team will record the temperature and humidity level of the chilling room. Lastly, the employees will grade, pack, and send the carcasses to the delivery logistics team.

\section{Foundational architecture-HARA Ledger}

The Halal labeling traceability system is built on HARA Ledger, a consortium blockchain based on features of Ethereum with Proof of Authority (PoA) protocol. Like a cooperative model, a group of companies (with predefined nodes) governs the semidecentralized blockchain environment. The consortiumbased blockchain provides security inherited from public blockchains, as it operates under the leadership of a group instead of a single entity and many of the same advantages as a private blockchain (Figure 3 ).

The HARA Ledger Traceability Ecosystem combines off-chain private applications and services (for data input), private chain, 
HARA Ledger Traceability Ecosystem
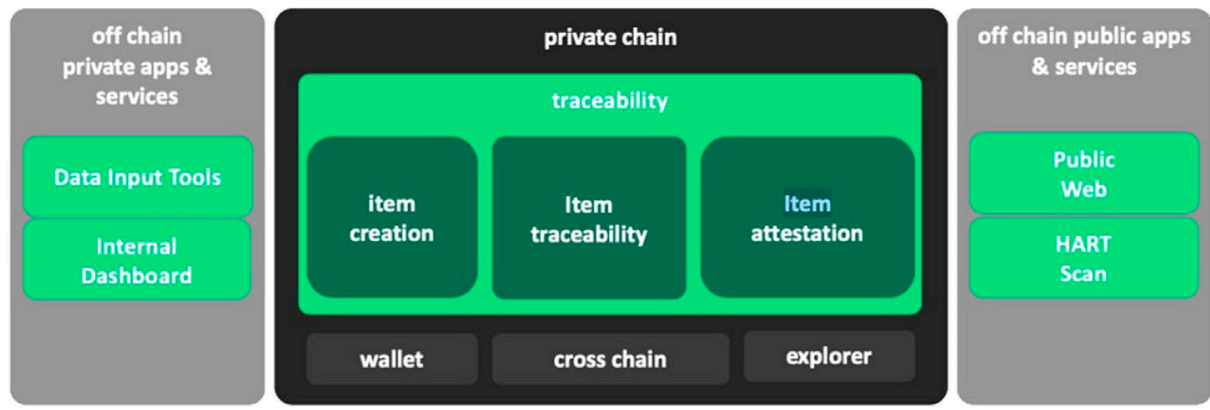

FIGURE 4 | HARA Ledger Traceability Ecosystem. Source: HARA (2020). Internal Company Data. HARA.

and off-chain public apps and services (Figure 4). Smart contracts are used for the traceability module, which requires attestation through various points of the journey. All activities that occur within the network can be monitored on Netstats.

\section{Technology Implementation}

Implementing the blockchain-based traceability system in Sreeya Sewu proved to be more difficult, as it required an overall digitization of data recording throughout the production process. Initially, data entry and reporting mechanisms were redundant. Information was handwritten on paper, then entered into a spreadsheet system, which would then be printed out. Hard-copy reports were then sent to the next production process. Records were kept in silos per division, causing difficulty in tracing the journey of the same poultry batch even within the same slaughterhouse. As it took time to digitize the reports, data compilation for production analysis was only done monthly. An integrated record system tools and automation of processes needed to be introduced to realize data transparency in the halal production process.

Key features introduced to create the blockchain-based traceability system implemented in Sreeya Sewu included the following:

- Real-time data input tools

Data input automation to minimize human errors in repeated manual input. These input tools were handled by various production teams, such as the inspection team, slaughterer team, and quality control team. For each checkpoint, the production teams would input the findings through their devices. This eliminates the redundancy of moving data from manual records to excel files, which would then be printed out and sent to other divisions to continue the process. With the realtime data input, the other divisions could directly see the inputted information.

\section{- Blockchain-based platform}

The blockchain-based platform ensures both the data transparency and data integrity of the journey of the poultry.
As a consortium-based blockchain, information can be accessed by parties within the network. With the encryption nature of blockchain, it is also difficult to tamper with information as the unique hash will be replaced when information is changed.

\section{- Traceability site}

A public traceability site allows consumers to trace the production process of purchased poultry via a QR code. Information includes the handling journey, individuals involved in the process, and Halal certification of relevant parties. Traceability information comes in the form of network graphs for ease of reading.

- Internal dashboard analytics

With real-time data input from the slaughterhouse, Sreeya Sewu's management team can monitor and analyze production activities and key performance indicator reports of the slaughtering process on demand. Information analyzed ranges from which farms have the best products as well as statistics on poultry defects.

\section{RESULT: ENHANCING HALAL INTEGRITY AND EFFICIENCY IN THE ENTIRE PROCESS}

As traceability allows data transparency of the processes, data integrity can be maintained. Before Sreeya Sewu implemented the traceability system, information to consumers was limited to the Halal logo. The blockchain-based traceability system allows consumers to review the journey information from farm to table, adding an extra layer of confidence towards the integrity of its Halal label. Consumers can scan the QR code on the product to gain information on the journey of the poultry and even check the certification of the poultry slaughterer.

The digital transformation overhaul to integrate the blockchain system creates room for operational improvements. With real-time data input tools and transparent recordkeeping, manual processes were not only streamlined, but Sreeya Sewu's 
management was also able to analyze reports using granular information on-demand.

The inherent risk of this system is that it does not stop incorrect information from being recorded. However, the immutability feature of blockchain technology encourages the production team to be more careful. Sreeya Sewu's production teams understand that once data is recorded, it is permanent. Attestation in each process includes a timestamp and employee ID, so it can be traced to whoever inputs the data if incorrect information were uploaded. Thus, the traceability system allows better supervision of the entire production process in the slaughterhouse.

This research is a promising initial study on the use case of blockchain-based Halal traceability systems implemented in the poultry industry. To discover the extent of the effectiveness of the system will need time. Several ways to optimize the study will be to conduct a customer sentiment survey towards the confidence of the Halal labeling process, in relation to sales numbers, and investigate operational efficiency within the supply chain due to real-time information availability. Also, extending the process flow of data input from the farm level will strengthen the Halal labeling process from end to end. This will provide a more accurate and deeper understanding of the effects of implementing blockchain-based traceability systems.

\section{CONCLUSION}

A system that enhances the transparency of the poultry from farm to fork is critical to ensure the integrity of the Halal labeling process. Traceability plays a vital role in promoting information transparency throughout the supply chain, and the decentralized and immutable nature of the blockchain technology prevents data tampering. This research is a promising initial study on implementing blockchain-based traceability systems to monitor the Halal labeling process assessment at PT Sreeya Sewu Indonesia. To find out more about the effectiveness of

\section{REFERENCES}

Abidin, N. Z., and Perdana, F. F. (2020). A Proposed Conceptual Framework for Blockchain Technology in Halal Food Product Verification. J. Halal Industry Serv. 3, 2637-0891. doi:10.36877/jhis.a0000079

Ali, M. H., and Suleiman, N. (2016). Sustainable Food Production: Insights of Malaysian Halal Small and Medium Sized Enterprises. Int. J. Prod. Econ. 181, 303-314. [online] Available at:https://www.sciencedirect.com/science/article/ abs/pii/S0925527316301086. doi:10.1016/j.ijpe.2016.06.003

Anonymous (2014). Cadbury is Halal. NST. Available at: https://www.nst.com.my/ amp/news/2015/09/1292/cadbury-halal.

Anir, A. N., Nizar, M. N., and Masliyana, A. (2008). "RFIG Tag for Halal Food Tracking in Malaysia: Users Perceptions and Opportunities," in 7th WSEAS International Conference on TELECOMMUNICATIONS and INFORMATICS (TELE-INFO '08)

Asia Blockchain Review (2019). Blockchain for Food Traceability in the Halal Food. Available at: https://www.asiablockchainreview.com/blockchain-forfood-traceability-in-the-halal-food-industry/ (Retrieved June 1, 2020).

Asia Blockchain Review (2016). What Is Halal? A Guide for Non-muslims. Available at: https://www.icv.org.au/about/about-islam-overview/what-ishalal-a-guide-for-non-muslims/ (Retrieved June 26, 2020). this system will require a longer period to assess postimplementation. In the future, research should be done to measure the trust level of consumer towards poultry products recorded on the blockchain platform.

\section{DATA AVAILABILITY STATEMENT}

The original contributions presented in the study are included in the article/Supplementary Material, further inquiries can be directed to the corresponding author.

\section{ETHICS STATEMENT}

Ethical review and approval was not required for the animal study because this study reports findings of a traceability system implemented on the production of Halal-labeled poultry in Indonesia. Written informed consent was obtained from the owners for the participation of their animals in this study.

\section{AUTHOR CONTRIBUTIONS}

All authors listed have made substantial, direct, and intellectual contribution to the work and approved it for publication.

\section{ACKNOWLEDGMENTS}

The authors would like to express their deepest gratitude to HARA CTO Imron Zuhri for his relentless efforts to improve the use of technology of the status quo and HARA Sr. Blockchain Engineer Lead Juwita Winadwiastuti and Arianne Santoso for assisting with the writing process. Special thanks go to the Sreeya Sewu team, who took the leap of faith to overhaul data recordkeeping processes throughout the production line.

ASEAN Post Team (2019). The Booming Halal Industry. Available at: https:// theaseanpost.com/article/booming-halal-industry (Retrieved May 27, 2020).

Deloitte (2020). Using Blockhain to Drive Supply Chain Transparency. Available at: https://www2.deloitte.com/us/en/pages/operations/articles/blockchainsupply-chain-innovation.html (Retrieved June 26, 2020).

Detik (2019). Tak Lagi Berwenang, MUI Dukung Sertifikasi Halal Dikeluarkan BPJPH. Available at: https://m.detik.com/news/berita/d-4748379/tak-lagiberwenang-mui-dukung-sertifikasi-halal-dikeluarkan-bpjph (Retrieved June 26, 2020).

FAO (2017). Food Traceability Guidance. Santiago: Food and Agriculture Organization of the United Nations.

Dinar Standard (2019). State of the Global Islamic Economy Report DRIVING THE ISLAMIC ECONOMY REVOLUTION 4.0 [online]. Available at: https:// cdn.salaamgateway.com/special-coverage/sgie19-20/full-report.pdf

Haq, M. (2019). Sertifikasi Halal Kini Dikeluarkan BPJPH, Menag: Fatwa Masih Wewenang MUI. Available at: https://news.detik.com/berita/d-4748264/ sertifikasi-halal-kini-dikeluarkan-bpjph-menag-fatwa-masih-wewenang-mui/ 1. (Retrieved May 27, 2020).

Hidayat, M. (2012). MUI Jawab Soal Daging Haram Berlabel Halal. Available at: https://metro.tempo.co/read/448404/mui-jawab-soal-daging-haram-berlabelhalal/full (Retrieved May 27, 2020). doi:10.1063/1.4724157 
Ibrahim, O., Samsi, S., and Tamsin, R. (2012). Review on Knowledge Management as a Tool for Effective Traceability System in Halal Food Industry Supply Chain. J. Res. Innovat. Information Syst. 1, 78-85.

Kamaruddin, R., Iberahim, H., and Hamid, N. (2011). "Halal Global Analytic Hierarchy Parameters: A Conceptual Assessment," in The 12th International Symposium on the Analytical Hierarchy Process. Kuala Lumpur: Multi Criteria Decision Making.

Kamath, R. (2018). Food Traceability on Blockchain: Walmart's Pork and Mango Pilots with IBM. The JBBA 1 (1), 1-12. doi:10.31585/jbba-1-1-(10)2018

Karssing, E. D. (2007). Morele Competentie in Organisaties [Moral Competence in Organizations]. Assen, Netherlands: Van Gorcum. (Original work published 2001).

Khasanab, J., and Wardah, W. (2018). The Implementation of Halal Food Labeling Based on the Technical Barriers to Trade (TBT) Agreement by Indonesia. Jurnal Ilmiah Mahasiswa Bidang Hukum Kenegaraan 2 (3), 650-662.

Kurnia, T. (2019). Berlaku 17 Oktober, Simak Isi Aturan Produk Wajib Sertifikasi Halal. Available at: https://www.liputan6.com/bisnis/read/4087698/berlaku-17-oktobersimak-isi-aturan-produk-wajib-sertifikasi-halal (Retrieved June 30, 2020).

Lipka, M., and Hackett, C. (2017). Why Muslims Are the World's Fastest-Growing Religious Group. Available at: https://www.pewresearch.org/fact-tank/2017/04/ 06/why-muslims-are-the-worlds-fastest-growing-religious-group/ (Accessed June 26, 2021). doi:10.1109/group4.2017.8082198

Lithalia (2016). 3 Cara Cek \& Daftarkan Sertifikasi Halal via Aplikasi Halal MUI. Available at: https://jurnalapps.co.id/3-cara-cek-daftarkan-sertifikasi-halal-viaaplikasi-halal-mui-1677 (Retrieved June 29, 2020).

Mayasari, D. (2018). Pentingnya Sertifikasi Halal Pada Sebuah Produk. Available at: https://www.timesindonesia.co.id/read/news/173725/pentingnyasertifikasi-halal-pada-sebuah-produk (Retrieved June 26, 2020).

MUI (2019). FAQ Sertifikasi Halal. Available at: https://www.halalmui.org/muil4/ main/page/faq-sertifikasi-halal (Retrieved June 30, 2020)

MUI (2020). Persyaratan Sertifikasi Halal MUI. Available at: https://www. halalmui.org/muil4/main/page/persyaratan-sertifikasi-halal-mui (Retrieved June 26, 2020).

Norman, A., Md Nasir, M., and Masliyana, A. (2008). RFID Tag for Halal Food Tracking in Malaysia: Users Perceptions and Opportunities. Available at: https://www.researchgate.net/publication/242698680_RFID_Tag_for_Halal_ Food_Tracking_in_Malaysia_Users_Perceptions_and_Opportunities

Rahim, A., and Ma'aram, A. (2016). Halal Traceability in Enhancing Halal Integrity for Food Industry in Malaysia - A Review. Int. Res. J. Eng. Technology (Irjet) 3 (3), 68-74.

Rahman, S. (2017). Religion and Animal Welfare-An Islamic Perspective. Animals 7, 11, 2017 . [online] Available at:https:/www.ncbi.nlm.nih.gov/pmc/articles/ PMC5332932/. doi:10.3390/ani7020011

Rashid, N. A., Supian, K., and Bojei, J. (2018). Relationship between Halal Traceability System Adoptions on Halal Food Supply Chain Integrity and Performance. Int. J. Asian Soc. Sci. 8 (8), 569-579. doi:10.18488/ journal.1.2018.88.569.579

Reiff, N. (2020). Blockchain Explained. Available at: https://www.investopedia.com/ terms/b/blockchain.asp\#: :text=Each\%20computer\%20in\%20the\% 20blockchain,copies\%20of\%20the\%20same\%20blockchain (Retrieved June 02, 2020)

Rejeb, A. (2018). Halal Meat Supply Chain Traceability Based on HACCP, Blockchain and Internet of Things. Acta Tech. Jaur 11 (4), 218-247. doi:10.14513/actatechjaur.v11.n4.467
Rejeb, A., Keogh, J. G., Zailani, S., Treiblmaier, H., and Rejeb, K. (2020). Blockchain Technology in the Food Industry: A Review of Potentials, Challenges and Future Research Directions. Logistics 4 (4), 27. doi:10.3390/logistics4040027

Riana, F. (2019). Simak, Begini Alur Proses Sertifikasi Halal Menurut BPJPH. Available at: https://nasional.tempo.co/read/1275694/simak-begini-alurproses-sertifikasi-halal-menurut-bpjph/full\&view=ok (Retrieved June 26, 2020).

Rios, R., Riquelme, H., and Abdelaziz, Y. (2014). Do Halal Certification Country of Origin and Brand Name Familiarity Matter? Asia Pasific J. Marketing Logistics 26 (5), 665-686. doi:10.2208/APJML-03-2014-0046

Saifudin, A. M., Siti, O., and Ezanee, E. (2017). Exploring in Setting a Model for Islamic Supply Chain in Malaysia. Int. Rev. Management Marketing 7 (1), 95-102.

Spink, J., Bedard, B., Keogh, J., Moyer, D. C., Scimeca, J., and Vasan, A. (2019). International Survey of Food Fraud and Related Terminology: Preliminary Results and Discussion. J. Food Sci. 84 (10), 2705-2718. doi:10.1111/17503841.14705

Tempo (2012). MUI Jawab Soal Daging Haram Berlabel Halal. Available at: https:// www.google.com/amp/s/metro.tempo.co/amp/448404/mui-jawab-soal-dagingharam-berlabel-halal (Retrieved June 26, 2020).

Viriyasitavat, W., and Hoonsopon, D. (2019). Blockchain Characteristics and Consensus in Modern Business Processes. J. Ind. Inf. Integration 13, 32-39. doi:10.1016/j.jii.2018.07.004

Withnall, A. (2014). Halal Meat: What Is it and Why Is it So Controversial. Available at: https://www.independent.co.uk/life-style/food-and-drink/whatis-halal-meat-the-big-questions-about-religious-slaughter-answered-9331519. html (Retrieved June 26, 2020).

Zailani, S., Arrifin, Z., Wahid, N. A., Othman, R., and Fernando, Y. (2010). Halal Traceability and Halal Tracking Systems in Strengthening Halal Food Supply Chain for Food Industry in Malaysia (A Review). J. Food Tech. 8 (3), 74-81. doi:10.3923/jftech.2010.74.81

Conflict of Interest: LS reports affiliation with the blockchain-based technology company involved in implementing the traceability system discussed in this manuscript.

The remaining author declares that the research was conducted in the absence of any commercial or financial relationships that could be construed as a potential conflict of interest.

Publisher's Note: All claims expressed in this article are solely those of the authors and do not necessarily represent those of their affiliated organizations, or those of the publisher, the editors and the reviewers. Any product that may be evaluated in this article, or claim that may be made by its manufacturer, is not guaranteed or endorsed by the publisher.

Copyright (๑) 2021 Sidarto and Hamka. This is an open-access article distributed under the terms of the Creative Commons Attribution License (CC BY). The use, distribution or reproduction in other forums is permitted, provided the original author(s) and the copyright owner(s) are credited and that the original publication in this journal is cited, in accordance with accepted academic practice. No use, distribution or reproduction is permitted which does not comply with these terms. 